\title{
THE RIGHT TO HOUSING IN THE CONTEXT OF NIGERIAN LAW AND HUMAN RIGHTS PRACTICE
}

\author{
E. Chegwe
}

\section{Emeke Chegwe}

LL.M, PhD, BL, Senior Lecturer and Former Head of Department of Jurisprudence and International Law, Delta State University, Nigeria.

Email: chegweemeke@yahoo.com

\section{Abstract}

Every society needs a set of laws which stipulates the rights and duties of citizens, as well as regulate the conduct of the society. But law is often perceived as repressive and unpopular by majority of the urban poor in many developing countries who feel that the law has done little or nothing to ameliorate their sufferings. For example, new evidence from satellite images has revealed the true extent of forced evictions going on in Badia East-Lagos, one of Nigeria's mega cities. The pictures taken during and after the demolitions carried out by the Lagos State government on $23^{\text {rd }}$ February 2013, clearly shows that a densely populated area containing concrete housing and other structures was razed to the ground. Given the importance of housing to the overall development and existence of mankind, it is necessary to first determine the existence of a legal right to adequate housing to warrant a demand by the citizen to fulfil this right and in order to appreciate the need for government intervention in this area.

\section{Keywords: Housing, Human Right, Nigerian, Practice, Law}

\section{Introduction}

The right to adequate housing, which forms the subject matter of this paper, is one of the economic, social and cultural rights, which has been guaranteed by a number of local and international laws. But their enjoyment in Nigeria falls short of the growing expectations of Nigerians in their desire to have them elevated to the status of fundamental human rights. This desire is a fall out from economic pressures, which have led to the emergence of extremely wealthy people on the one hand, who can afford the best houses, and of poverty-ridden people, who live in shacks in the cities and are in constant fear of being homeless on the other hand. It has therefore been suggested that a great proportion of national wealth should not be enjoyed only be a handful of persons to the exclusion of the less privileged in the society. ${ }^{1}$ Surprisingly, there are a number of international human rights conventions, which duly provide for a right to adequate housing. Nigeria is a signatory to these international conventions and has also ratified a number of them. ${ }^{2}$ At the national level, the right to housing is recognised in the constitution and other laws enacted at other levels which impact upon housing. The Fundamental Objectives and Directive Principles of State Policy of the 1999 Constitution Provides, inter alia, that the "state shall direct its policy towards ensuring that

\footnotetext{
${ }^{1}$ See V. Kartashkin, "Economic, Social and Cultural RIghts" in K. Vasak and P. Alston, eds, The International Dimension of Human Rights (Westport, TC: Greenwood Press, 1982), pp. 111 - 134.

${ }^{2}$ See e.g. African Charter on Human and People Rights, OAU, DOC, CAB/LEG/67/3/Rev. 4. It entered into force on 21 October, 1996. Nigeria has ratified same as at 1 January, 1996. See, e.g., African Charter on Human and People Rights (Ratification and Enforcement) Acts Cap. 10 LFN 1990. See further, The International Covenant on Economic Social and Cultural (ICESCR) Rights. As of January 1996, 134 countries had ratified the covenant. See 17 HRLJ 66 (1996). Nigeria ratified it in 1993.
} 
suitable and adequate shelter, suitable and adequate food, reasonable national minimum wage, old-age care and pensions, and unemployment and sickness benefits are provided for all citizens". ${ }^{3}$ Closely tied to this provision are the various Rent Control and Recovery of Residential Premises Laws and Edicts in different states in Nigeria, which serve to give meaning and significance to the existence of a right to housing. Many of these laws reinforce the position that tenants in residential housing are entitled to adequate housing like their landlords and that tenants should neither be charged arbitrary rents, nor be evicted without due process of law.

Thus, there is a de jure acknowledgement of the right to housing in Nigerian domestic law. However, the housing problem has not generally been approached from a human rights perspective. Thus, the laws relating to housing may be with some degrees of exaggeration, be stated to be more honoured in breach than in observance, moreover, there is an emerging trend towards enactment of anti-housing laws in recent years. ${ }^{4}$ The socio-economic forces currently at play in the country have cast serious doubts on the ability of the ordinary Nigerian to realize his rights to adequate housing. Rather, from the narrow construction of the fundamental rights provided in the various Nigerian Constitutions, housing rights have been relegated to the background of professional legal discourse. ${ }^{5}$ Considering their importance to the majority of the population, particularly the most vulnerable segments of the society, it has become clear that an approach for the judicial enforcement and actualisation of the right to adequate housing needs to be devised.

This paper attempts an analysis of the existing rights on the entitlement of individuals to adequate housing in Nigeria. It further evaluates these rights in terms of internationally accepted norms concerning the rights of the individual to adequate housing in relation to other basic rights, and determines the extent to which these norms are practiced in Nigeria.

\section{Right to Housing: Its Human Right Pedigree}

Adequate housing is a right, which has been described as one of the basic needs of man. ${ }^{6}$ As such, it is of prime importance for the realisation of the full potential of the human personality. Despite the pessimism expressed in certain quarters ${ }^{7}$ about the nature of economic, social and cultural (ESC) rights as rights properly so- called, it has been affirmed that adequate housing is universally viewed as one of the most basic human rights. For human rights generally, there are several definitions, including that proffered by scholars and jurists. ${ }^{8}$ At the level of case law, Kayode Eso JSC in Ransome Kuti vs. Attorney General of the Federation described human rights thus: "....it is a right which stands above the ordinary laws of the land and which, in fact, is antecedent to political society itself. It is a primary condition for a civilized existence, and what has been done by our constitution since independence is to have these rights enshrined in the constitution so that the rights could be immutable to the extent of the non- immutability of the constitution itself",

The Greek and Roman philosophers of the Stoic school, who first formulated the concept of natural law, maintained that natural law is universal because it applies not only to

\footnotetext{
${ }^{3}$ The constitutional position of non-justiciability has denied the existence of right to adequate housing and other ESC rights which suffer the same fate under Section 6(6)(c). See e.g., Okojie vs. Attorney General of Lagos State (1981) 2 NCLR 337, where the Court of Appeal held that by virtue of Section 6(6)(c), no court has jurisdiction to pronounce any decision in conformity or otherwise with chapter two.

${ }^{4}$ See the Land Use Act, which made every Nigerian a tenant of the Federal Government.

${ }^{5}$ Shelter Rights Initiative, Housing Right Protection Strategies for Lower Court Judges (2000).

${ }^{6}$ Food and clothing are also classified as other basic necessities of life.

${ }^{7}$ Supra, see note 3 .

${ }^{8}$ Butchers Union vs. Crescent City Co. (1883) 28 Led 585; "The rights (i.e. those guaranteed by the bill of rights) are different from the concrete rights which a man may have to a specific chattel or to a piece of land or to the performance by another of a particular contract...they are the capacity, power or privilege of having or enjoying those concrete rights and of maintaining them in courts".

9 (1985) 2 NWLR (Pt 61) 211 at 230.
} 
citizens of certain states but rather to everybody everywhere in the metropolis. It is superior to every positive law and embodies those elementary principles of justice, which were apparent to the "eye of reason". According to Cicero: "it is of universal application, unchangeable and everlasting ... it is a sin to try to alter this law, nor is it allowable to try to repeal any part of it, and it is impossible to abolish it entirely. We cannot be free from its obligation by Senate or people ... And there will not be different laws at Rome or at Athens or different laws now and in the future, but one eternal and unchangeable law will be valid for all nations and for all times. ${ }^{10}$ The natural rights, which emanated from it, were "not the particular privileges of citizens of certain state, bill something to which every human being, everywhere, was entitled". ${ }^{11}$

The general appeal of the idea of natural law continued through the middle ages but the concept suffered a temporary set-back thereafter, due partly to the popularity of the teaching of Machiavelli ${ }^{12}$ and partly to the absolutisms of the new and emerging nation-states in the early part of the $16^{\text {th }}$ century. It was, however, revitalized in the $16^{\text {th }}$ and $17^{\text {th }}$ centuries by two factors. The first was the Reformation, which resulted in bitter religious struggles in Europe. This, in turn, brought about a widespread outcry for the natural rights of freedom of conscience and religious belief.

Human rights are of two broad categories. The first category of civil and political rights is sometimes viewed or otherwise known as liberty-oriented ${ }^{13}$ rights or first generation rights. These include the right to life; right to personal security; freedom of thought, conscience and religion; freedom of opinion and expression, peaceful assembly and association; freedom from slavery and servitude, and freedom from torture or cruel, inhuman or degrading treatment or punishment. These are rights asserted against the state for the protection of the liberty of the individual.

The other category of rights consists of the economic, social and cultural rights. They are also known as security-oriented rights or second-generation rights. These include the right to work, to just and favourable condition of work, to form and join trade unions, to social security, to protection of family life, to adequate standard of living, to education, and to take part in the cultural life of one's society. In the $18^{\text {th }}$ and $19^{\text {th }}$ centuries, only civil and political rights featured prominently in political discourse at the national levels and were incorporated in many of the constitutions adopted at the time. Economic, social and cultural rights were at the time considered merely as by-products of civil and political rights. However, from the early $20^{\text {th }}$ century, states started to place emphasis on socio- economic rights. Hence, these became incorporated in the Constitutions of the United State, of Mexico, the Russian Soviet Federated Socialist Republics, the Western Republic of Germany, the Spanish Republic, the former USSR and Ireland in 1917, 1918, 1919, 1931, 1937 and 1938 respectively. ${ }^{14}$ Following the establishment of the United Nations at the end of the Second World War and the adoption of the Universal Declaration of Human Rights which recognized both civil and

10 The Republic NXXII 33 quoted in Text for Human Right Teaching in Schools, a Publication of the Constitutional Right Project, 1999.

${ }^{11}$ Cranston, M., Human Rights Today (1962) p. 9.

12 See The Prince (Translated by George Bull) in which Machiavelli (1496 - 1527) taught the princes how to acquire and retain principalities.

13 David Selby, Human Rights (Cambridge, The Cambridge University Press, 1987). There are also third generation rights otherwise known as solidarity rights. They include the right of development, the right to health and balanced environment, the right to communicate, the right to be different, the right to benefit from the common heritage of mankind and the right to humanitarian assistance. This category of rights is still evolving. Not all the rights listed above are supported by everybody. The number may increase or contract in the future. See Karel Vasak "The Third Generation of Human Rights: The Right of Solidarity". Inaugural Lecture at the tenth Session of the International Law of Human Right Conference Strasbourg, 2 - 7 July, 1979, pp. 2 - 27; Keba Mbaye International Law; Achievements and Prospects (UNESCO, 1991) p. 1055. Bedjaoui (ed).

${ }^{14}$ See Valdimiri Kartashkin "Economic, Social and Cultural Rights" in The International Dimensions of Human Rights (ed) Acronym Vasak, (1992) UNESCO, p. 111. 
political rights, as well as the economic, social and cultural rights, the recognition of the latter has become widespread.

The question is: Is the enjoyment of these sets of rights divisible? In other words, should their enjoyment be prioritized so that the enjoyment of economic, social and cultural rights is postponed or accorded less emphasis, while the civil and political rights are enjoyed or vice versa? Or is the enjoyment of the rights indivisible, so that all of them should be insisted upon concurrently.

\section{Content of the Right to Housing}

An appreciation of the content of the right to adequate housing will assist in understanding the level of protection encompassed by the right to adequate housing. It has been submitted that: "At first glance it might seem unusual that a subject such as housing would constitute an issue of human rights. However, a look at national and international laws, as well as the significance of a secure place to live for human dignity, physical and mental health and overall quality of life, it begins to reveal some of the human rights implications of housing...

Under General Comment No. 4 of the UN Committee on Economic Social and Cultural Rights, which is relevant to the right to adequate housing, seven functional parameters are enumerated, to wit: legal security of tenure, affordability, availability of materials, services and infrastructure, habitability, accessible location and cultural adequacy:

a. Legal Security of Tenure: tenure takes a variety of forms, including rental (public and private) accommodation, co-operative housing, lease, owner - occupation, emergency housing and informal settlements, including occupation of land and property. Regardless of the type of tenure, all persons should possess a measure of security of tenure, which guarantees legal protection from forced eviction, harassment and other threats. State parties should, consequently, take immediate measure aimed at conferring legal security of tenure upon those persons lacking such protection in consultation with affected persons and groups.

b. Availability of Services, Materials, Facilities and Infrastructure: Adequate housing must contain facilities essential for health, security, comfort and nutrition. All beneficiaries of the right to adequate housing should have sustainable access to natural and common resources, safe drinking water, energy for cooking, heating and lighting, sanitation and washing facilities, means of food storage, refuse disposal, site drainage and emergency services.

c. Affordability: Personal or household financial costs associated with housing should be at such levels that the attainment and satisfaction of other basic needs are not threatened or compromised. Steps should be taken by State parties to the convention to ensure that the percentage of housing related costs is, in general, commensurate with income levels. State parties should establish housing subsidies for those unable to obtain affordable housing, as well as forms and levels of housing finance, which adequately reflect housing needs. In accordance with the principle of affordability, tenants should be protected by appropriate means against unreasonable rent levels or rent increase. In societies where natural materials constitute the chief resources of building materials for housing, steps should be taken by state parties to ensure the availability of such materials.

d. Habitability: Adequate housing must be habitable, in terms of providing the inhabitants with adequate space and protection them from cold, damp, heat, rain, wind or other threats to health, structural hazards, and disease vectors, the physical safety of occupants must be guaranteed as well. The committee encourages State parties to comprehensively apply the Health Principles of Housing prepared by WHO, which view housing as the environmental factors most frequently associated with conditions for disease in

\footnotetext{
${ }^{15}$ World Campaign for Human Rights: Fact Sheet No. 21 on the Right to Adequate Housing at p. 3.
} 
epidemiological analysis; i.e. Inadequate and deficient housing and living conditions are invariably associated with higher mortality and morbidity rates.

e. Accessibility: Adequate housing must be accessible to those entitled to it. Disadvantaged groups must be accorded full and sustainable access to adequate housing resources. Thus, such disadvantaged groups as the elderly, children, the physically disabled, the terminally ill, HIV -positive individuals, persons with persistent medical problems, the mentally ill, victims of natural disasters, people living in disaster-prone areas and other groups should be ensured some degree of priority consideration in the housing sphere. Both housing law and policy should take fully into account the special housing needs of these groups. Within many State parties, increased access to land by landless or impoverished segments of the society should constitute a central policy goal. Discernible governmental obligations need to be developed, aiming to substantiate the right of all to a secure place to live in peace and dignity, including access to land as an entitlement.

f. Location: Adequate housing must be in a location which allows access to employment options, health-care services, schools, child-care centres and other social facilities. This is true both in large cities and in rural areas, where the temporal and financial costs of getting to and from the place of work can place excessive demands upon the budgets of poor households. Similarly, housing should not be built on polluted sites or in immediate proximity to pollution sources that threaten the right to health of the inhabitants.

g. Cultural Adequacy: The way housing is constructed, the building materials used and the policies supporting these must appropriately enable the expression of cultural identity and diversity of housing. Activities geared towards development or modernization in the housing sphere should ensure that the cultural dimensions of housing are not scarified, and that, inter alia, modern technological facilities, as appropriate, are also ensured.

It is clear, from the foregoing, that the right to adequate housing is not limited to any kind of house; neither does the right translate merely into a right to a house built by the state on demand. Adequate housing means more than mere shelter, since it embraces all the social services, utilities and facilities that make a neighbourhood. The law and policy supporting housing rights must assist in the evaluation of the adequacy of housing in every given country. The law can reveal whether the state for instance, encourage the practice of forced eviction or discrimination in housing policies. Thus, considering Nigeria cannot isolate herself from the international community, the goal of her housing policy must reflect the various United Nations agreements which are expressed in conventions. Lastly, since the right to housing is a life-long right, its implications must allow for changing needs. Thus, even when the right to housing is often expressed in terms of possession of houses, the concept of housing is sufficiently all embracing and certainly goes beyond shelter from the elements.

\section{Sources of Right to Adequate Housing:}

The right to adequate housing derives its status as a right from a number of national and international law provisions. It is a right, which has been identified as one of the basic needs of man. ${ }^{16}$ As such, it is of prime importance for the realisation of the full potential of the human personality. Though housing rights are derived from two backgrounds, namely municipal and international law, the two systems influences and impact on each other. In most jurisdictions, including Nigeria, Constitutional provisions require the incorporation of international law into municipal law before it becomes applicable as the basis for the decisions before the courts. ${ }^{17}$ There are various theories on the relationship between national and international laws as reflected in the Monism ${ }^{18}-$ dualism $^{19}$, Inverted monism ${ }^{20}$ and harmonisation schools of thought ${ }^{21}$.

\footnotetext{
${ }^{16}$ Today, Food and Clothing have been identified also as the other basic needs of man.

${ }^{17}$ See Section 12 of the Constitution.

${ }^{18}$ Propounded by Hans Kelsen and his disciples to the effect that international law and municipal law are all aspects of the system of laws.
} 


\section{Constitutional Provisions:}

At the national level, there is the constitutional provision found in the Fundamental Objectives and Directive Principles of State Policy, which in Section 16(2)(d) provides that the state shall direct its policy towards ensuring that suitable and adequate shelter is provided for all citizens. However, Section 6(6) (c) of the constitution declared the Fundamental Objectives and Directive Principles non-justiciable. ${ }^{22}$ But a court faced with the task of construing a document that impacts on the right to housing may use the Directives as an aid to discover the most appropriate construction that tallies with the Constitution. ${ }^{23}$ A learned commentator $^{24}$ aptly captured the problems in what he terms the "Source of law misconception" as follows:

"When lawyers classify socio-economic rights as unjusticiable, they confuse in my mind, two important rights - bearing normative orders - the Constitution as a rights founding source on one hand, and legislation as rights empowering source on the other. Although fundamental rights claims are often founded on the authority of the Constitution, there is no requirement that this must be invariably so. Constitutional protection of rights may offer the best guarantees, but sometimes Constitutions themselves can be used to found new legal claims arising from a state's greater capacity and ability to realise human rights..."

Therefore, while the test of justiciability may very well eliminate claims based on socio-economic rights arising via the Constitution, the test may not be relevant for socioeconomic rights claims founded on any other legal principle outside the constitutional documents. Section 44(1) of the constitution provides against the compulsory acquisition of property except in a manner and for a purpose prescribed by law that provides among other things:

(a). The prompt payment of compensation thereof, and

(b). To any person claiming such compensation right of access to the courts for the determination of his interest in the property and the amount of compensation to a court of law or tribunal or body having jurisdiction in that part of Nigeria.

Section 44(2) provides the exceptions to Section 44.

Section 44(2) of the Constitution provides as follows: nothing in subsection 1 of this section shall be construed as affecting any general law:

(a). For the imposition or enforcement of any tax, rate or duty;

(b). For the imposition of penalties or forfeitures for the breach of any law, whether under civil process or after conviction for an offence;

(c). Relating to leases, tendencies, mortgages, charges, bills of sale or any other rights or obligations arising out of contracts;

(d). Relating to the vesting and administration of the property of persons adjudged or otherwise declared bankrupt or insolvent, of persons of unsound mind or deceased persons, and of corporate and unincorporated bodies in the course of being wound up;

\footnotetext{
19 As postulated by Hegel that international law and municipal law are seen as two different systems of law, coming from two different sources.

${ }^{20}$ Inverted monism postulates that municipal law takes precedence over international law.

21 The Harmonisation theory rejects the monist and dualist approach to the resolution of conflict between municipal and international law. It canvasses that both laws are concordant bodies of doctrine, each autonomous in the sense that it is directed to a specific and to some extent, exclusive area of human conduct but harmonious in that in their totality the several rules aim at human welfare.

${ }^{22}$ The framers of the Constitution equated the right to housing to a right to housing on demand. As such, the non-justiciability reason was meant to shut out legal demands based on that interpretation of housing rights.

${ }^{23}$ See the decision of the court in Archbishop Okogie vs. Attorney General of Lagos State (1981) 2 NCLR 337.

${ }^{24}$ Joseph Otteh. The Challenges for Socio-Economic Right litigation in Nigeria: Hurdles and Prospects in Economic, Social and Cultural Rights in Developing a Training Agenda for Nigeria. (Lagos, Legal Research and Resource Development Centre Roundtable Series, 1998).
} 
(e). Relating to the execution of judgements or orders of courts;

(f). Providing for the taking of possession for property that is in a dangerous state or is injurious to the health of human beings, plants or animals;

(g). Relating to enemy property;

(h). Relating to trusts and trustees;

(i). Relation to limitations of actions;

(j). Relating to property vested in bodies corporate directly established by any law in force in Nigeria;

(k). Relating to the temporary taking of possession of property for the purpose of any examination, investigation or enquiry;

(1). Providing for the carrying out of work on land for the purpose of soil conservation.

\section{STATUTORY LAWS}

\section{(1). Rent Control and Recovery of Premises Laws}

Various recoveries of residential premises laws in different states in Nigeria provide for certain aspects of the right to housing, notably security of tenure. They usually make provisions for the legal procedure to be followed for the recovery of premises, the length of the notice, service, proceedings in court and issues to be considered by the court in arriving at a decision in recovery litigation. Rent control laws are focused on the affordability concept while laws on environmental health are geared to promote habitability. Most times, one enactment controls rent and recovery of premises. For instance, the Lagos State Rent and Recovery of Residential Premises law ${ }^{25}$ combines both functions. Arguments abound about the propriety of the state intervening in housing and the use of rent control as a policy instrument in favour of tenants. Investors in property and landlords have questioned the rationale behind regulating rents in a deregulated economy. The argument is that since other sectors of the economy are not regulated, why regulate the housing sector? This school of thought posits that tenants will be the ultimate losers as investors will move away funds from housing to more lucrative sectors of the economy. They conclude by insisting that the law of demand and supply, to wit: market forces, should be allowed to determine rent levels. Alternative arguments are that housing is a basic human right and need and cannot be allowed to be solely regulated by market forces. Allowing market forces to regulate rents will ensure that many individuals will not be able to afford adequate housing. This school of thought recognizes the need to curb the excesses of landlords, who, against all economic indices, charge outrageous rent. ${ }^{26}$ Hence, the statement of the European Court affirming a right to housing in the case of lames and Ors v. the United Kingdom ${ }^{27}$ is instructive:

Modern societies consider housing of the population to be a prime social need, the regulation of which cannot be left entirely to the play of market forces.

For similar development in the Asian States, reference is hereby made to the wise statement of Wilfred Wong, a Legislative Councillor in a speech on the Rent Increases and Domestic Premise Control Bill in Hong Kong, 1970 he stated.

"There is a common tendency to contend that the principle of the free play of the forces of supply and demand should at all times apply to the price of any commodity or accommodation. Suffice it to say that there is a difference between essential commodities such as foodstuff or housing, which are essential to living and luxury items which are not essential to life. We need only to read a little of economic history to note the importance of rent in the

\footnotetext{
${ }^{25}$ Made as Edict NO. 6 of 1997 In Imo State, the applicable law is the Landlord and Tenant Edict of 1994: for River States, it is the 1991 Recovery of Premises Law.

${ }^{26}$ See the Lagos State Rent Edict, 1997: A Public Operational Review - of the Human Rights Perspective by Eze Onyekepere. Unpublished paper presented at a workshop organized by the Nigerian Institute of Estate Valuers and Surveyors, March 1998.

${ }^{27}$ Also see the Lagos State Rent Edict 1997.
} 
economic development of any country and, indeed, th political repercussion of uncontrolled spiralling rents".

The provision of the Rent Control and Recovery of Residential Premises laws is made to control the rent of residential premises and the establishment of rent tribunals. They also determination what constitute standard rents and provide for recovery of possession. Thus, it has been stated by Oputa, JSC in Sule v. Cotton Board, ${ }^{28}$ about a similar legislation as follows: "The whole scheme and tenor of the Lagos Stare Rent Control and Recovery of Residential Premises Law especially in Sections 15 and 18 are to provide security of tenure and protection of tenants, including even a statutory tenant, and to restrict the recovery of premises from tenants unless the landlord complies with necessary formalities as to "Notice to Tenant of Owner's Intention to Apply for recovery of possession" as in form E followed by issue of writ or plaint against the tenant or person refusing to deliver up possession". ${ }^{29}$

Under the Rent Control and Recovery of Residential Premises Law, a tenant includes a substance or any person occupying any premises whether on payment or otherwise, but does not include a person Occupying premises on a bona fide claim to be the owner thereof ${ }^{30}$. This definition, when read in conjunction with Section 14 of the rent control laws, apparently abolishes the right of forcible entry of the landlord of a tenant at sufferance. As has been held in the following decided cases; African Petroleum vs. Owodunni, ${ }^{31}$ Oduye v. Nigerian Airways Ltd ${ }^{32}$ and Enigbokan v. Akinosho, the qualification of a tenant under the law is lawful occupation and if the initial occupation is lawful, the occupier, even if holding over after the determination of the tenancy by a notice to quit, becomes a protected tenant.

The nature of the protection that is offered to tenants by the Rent Control and Recovery of Residential Premises law is appreciated when one compares the powers of the landlord in the recovery of his premises under the common law from his power under the operation of the former. At common law, a landlord may sue to recover possession of his premises immediately upon the expiration of the term of the lease created. And where the term is periodic, he may proceed with his action immediately on the expiration of a valid notice to quit. The recovery of premises law now inserts a protection by providing that the landlord must, at the determination of the tenancy, serve on the tenant a seven day notice of his intention to proceed to recover possession. At the expiration of the seven days grace, the landlord may take out a plaint or writ in the prescribed form and his right to recover possession only takes effect upon a court order. All through the proceedings, the tenant is converted to a statutory tenant, who cannot be ejected by the landlord. As a statutory tenant he has a right to exclusive possession of the premises as against all others, including the landlord. This position is in contrast with the position at common law, where a tenant who refuses to yield up possession is treated as a trespasser vis-a-via the landlord.

(2). The Land Use Act

The Land Use $\mathrm{Act}^{33}$ is a legislation, whose implementation also affects the enjoyment of the right to adequate housing, particularly the accessibility of land and housing. From its recital, the intendment of the law is stated as follows: "an Act to vest all land comprised in the territory of each state (except land vested in the Federal Government or its agencies) solely in the Governor of the State, who would hold such and in trust for the people and would henceforth be responsible for allocation of land in all urban areas to individuals resident in the State and to organizations for residential, agricultural, commercial and other purposes

\footnotetext{
${ }^{28}$ Sule v. Cotton Board (1985) 2 NWLR (pt. 5) 17.

${ }^{29}$ See the interpretation of a tenant in Section 36 of the Rent Control Law.

${ }^{30}$ (1991) 8 NWLR (pt 210), 391, at 395.

${ }^{31}$ (1987) 2 NWLR (pt. 55), 126 at 147.

32 (1957) SCNLR 9 at 11-12.

${ }^{33}$ Cap L.5 Laws of the Federation of Nigeria, 2004.
} 
while similar powers with respect to nail-urban areas have been conferred on Local Governments". 34

The Act, which was described as intended to facilitate the availability of urban and rural land for development, has been termed a bold step aimed among others at: "protecting and preserving the rights of all Nigerians as beneficiaries to hold, use, and enjoy land in Nigeria; Reforming and harmonizing various land tenure systems in existence in the country before 1978; Regulating and controlling the use of land; Facilitating the processing of land acquisition by individuals, corporate bodies, institutions and governments, and eliminating land speculation". 35

The relevant provisions of the Act, which impacts on the rights to adequate housing, relates to interests on land by communities and individuals, which have been reduced to mere rights of occupancy and which can be revoked by the appropriate authority. In Nkwocha v. Governor of Anambra State \& Ors ${ }^{36}$ the Supreme Court stated of the Act as follows: "the tenor of the Act as a single piece of legislation is the nationalization of all lands in the country by the vesting of its ownership in the state leaving the private individuals with an interest in land, which is a mere right of occupancy and which is the only right protected in his favour by law after the promulgation of the Act".

Occupancy rights granted under the Act could be statutory or customary. While statutorily rights of occupancy ${ }^{37}$ are granted by the Governor of a state in respect of urban lands ${ }^{38}$, customary rights of occupancy are granted by a local government in respect of nonurban lands ${ }^{39}$. The governor, by virtue of Section 5 of the Act, has wide powers to grant statutory right of occupancy for all purposes, to demand rent for any such right which is granted to any person, to revise the said rent and to impose a penal rent. The governor may also revoke a right of occupancy for overriding public interest.

The effect of the continued provision of Section 21 and 22 is to forbid the alienation of both customary and statuary rights of occupancy without the consent of the governor first having been obtained. In view of the literal interpretation of this particular provision, the consent of the governor is required as a condition precedent to the creation of a valid landlord and tenant relationship, since the operative words are alienate or part with possession. The consent requirement has been stated to have a suffocating effect on domestic and commercial requirement for adequate housing.

\section{International Law}

A multiplicity of international conventions has made provisions for the right to adequate housing. First the provision of some binding treaties is hereby reproduced.

International Covenant on Economic, Social and Cultural Rights - Article 11(1)

The state parties to the present covenant recognise the right of everyone to an adequate standard of living for himself and his family, including adequate food, clothing and housing, and continuous improvement of living conditions. The state parties will take appropriate steps to ensure to this effect the essential importance of international appreciation based on enforced consent.

\section{International Convention on the Elimination of all Forms of Racial Discrimination, 1965}

Adopted and opened for signature and ratification by the General Assembly Resolution 2106 A (xx) of 21 December, 1965; Article 5 (e) (iii) of ICERD. In compliance with the fundamental obligations laid down in article 2 of this convention, states parties

\footnotetext{
${ }^{34}$ See National Housing Policy. Chapter 4. Section 44 on the Land Use Act 1978.

35 (1984) I SCNLR 634 . Quoted by Shelter Rights Initiative, supra note 5.at p. 26.

${ }^{36}$ See, Section $5(1)$ of the Act.

${ }^{37}$ See Section 6(1) of the Act.

${ }^{38}$ See Section 5(1)(a) - (h) of the Act.

${ }^{39}$ Prof. S.A. Oretuyi: Leases/Tenancies and the Consent Provision of the Land Use Act, 1978.
} 
undertake to prohibit and to eliminate discrimination on ground of race, colour or national or ethnic origin, to guarantee equality before the law in the enjoyment of the following rights.... (e) in particular (iii) The right to housing, Article 5 - (e) (iii).

International Convention on the Protection of the Rights of All Migrant Workers and Members of their Families (1990) Adopted December, 1990: Migrant workers shall enjoy equality of treatment with nationals. Secondly, there are international declarations and recommendations that impact on the right to Housing.

\section{Universal Declaration of Human Rights (1948)}

Adopted and proclaimed by the United Nations General Assembly (UNGA) Resolution 217A (iii) on 10 December, 1948. Everyone has the right to a standard of living adequate before the health and well being of himself and his family, including food, clothing and medical care and necessary social services, and the right to security in the event of unemployment, sickness, disability, widowhood, old age, or other lack of livelihood in circumstances beyond his control - Article 25 (1).

\section{Vancouver Declaration on Human Settlement (1976)}

Adopted by the UN conference on Human Settlement in 1976, Section III(8). Adequate shelter and service are basic human rights which places an obligation on governments to ensure the attainment by all people, beginning with direct assistance to the least advantaged through guided programmes of self-help and community action. Government should endeavour to remove all impediments hindering attainment of these goals. Of special importance is the elimination of better balanced communities, which blend different social groups, occupations, housing and amenities.

\section{(1986):}

Declaration of United Nations General Assembly on the Right to Development

Adopted by United Nations General Assembly Resolution 4/128 on 4 December, 1986, Article 8(1) states that "states should undertake, at the national levels, all necessary measures for the realisation of the development of and shall ensure, inter alia, equality of opportunity for all in their access to basic resources, education, health service, food, housing, employment and fair distribution of income". Effective measures should be undertaken to ensure that women have an active role in the development process. Appropriate economic and social reforms should be carried out with a view to eradicating all social injustices.

\section{Impact of International Conventions:}

Oliver Wendel Holmes stated that law is what the judge says and nothing more ${ }^{40}$. If that were so, then the most important person in the world of human rights, whether civil and political or economic, social and cultural, is the judge. Whatever the judge thinks about the status of enforceability of ESC rights may be more significant than what scholars and the theorists say. However, the assertion of the central role of judges in the protection of human rights does not detract from the fact that scholars do influence the opinion of judges. Be that as it may some decisions of the courts will now be examined to appreciate the position taken by the judiciary in the domestic application of international human rights. In Attorney General v. British Broadcasting Corporation" ${ }^{41}$, it was stated... "There is the presumption, albeit reputable, that our municipal law will be consistent with our international obligations". In Harris v. Ireland ${ }^{42}$ the European Court of Human Rights found Ireland in violation of the European Convention immediately after the Irish Supreme Court refused to be guided by a previous decision of the European Court having essentially the same fact. ${ }^{43}$

\footnotetext{
40 "The Prophecies of what the courts will do in fact and nothing more pretentious what I mean by law" - The Common Law (Boston, Little Brown \& Co. 1948).

41 (1981) Act 303.

42 (1968) 2 OB 740 at 757.

43142 Fur. Ct. H.R. (ser A) (1988).
} 
In Akinola v. General Babangida and others ${ }^{44}$ the appellant, a journalist and an officer of the Lagos State Council of the Nigerian Union of Journalists, instituted the action against the Federal Government of Nigeria. Ruling on a preliminary objection filed by the respondents, the High Court held that the court had jurisdiction to hear the case by virtue of Nigeria being a signatory to the African Charter on Human Rights, which preserves the jurisdiction of the courts. Hunponu Wugu J., referring to the decision of Onojala J. (as he then was) in the CRP case, said: "The learned jurist made copious reference to the African Charter on Human and Peoples Rights (Ratification and Enforcement) Act which is also an Act of the Federal Republic of Nigeria by virtue of cap 10 of the 1990 Laws of the Federation of Nigeria. It is a treaty and it is binding on the Federal Government. Since the Courts have held that the African Charter is like an enactment of the Federal Government, like a decree, it follows that if there is a conflict between an enactment ousting the jurisdiction of the court and another which does not, the courts should lean more on that which preserves the jurisdiction of the court". ${ }^{45}$

In Chief Fawehinimi v. General Abach and others, ${ }^{46}$ the appellant, inter alia, sought a declaration that his arrest and detention constituted a gross violation of his fundamental rights, and a mandatory order compelling the respondents to release him. He also sought an injunction restraining the respondents from arresting or detaining him. The appellant based his action not only on Section 31, 32, and 38 of the 1979 constitution but on Article 4, 5 and 12 of the African Charter on Human and Peoples Rights (Ratification and Enforcement) Act. The respondents raised a preliminary objection to the effect that the appellant was detained pursuant to a detention order made by the Inspector-General of Police, under the provision of the State Security (Detention of Persons) Decree No 2 of 1984, as amended and, consequently, the court had no jurisdiction to hear the action in that its jurisdiction was ousted by the Decree. The appellant's counsel in his argument contended that the Inspector General had no power to issue the detention order in that Decree No 11 of 1984, which sought to vest him with that power was otiose: that the provisions of the said Decree are inferior to and cannot override the provision of the African Charter on Human and Peoples' Rights. The learned trial judge upheld the preliminary objection and struck out the suit of the appellant. On appeal, the Court of Appeal held as follows:

1. The provisions of the African Charter on Human and Peoples Rights are in a class of their own and do not fall within the classification of the hierarchy of local legislation in Nigeria in order of superiority.

2. The African Charter as embodied in cap. 10, Laws of the Federation of Nigeria, 1990 is a law to which the court, the executive and the legislature, that is the Provisional Ruling Council under the present dispensation by virtue of Section 10(2) of Decree No. 107 of 1993, must give due recognition and enforce. The law is in full force and because of its genesis, it has an aura of inviolability unlike most municipal laws and may, as long as it is in the statue book, be clothed with vestment of inviolability. Consequently, the learned trail Judge erred in law in holding that because the provisions of the Charter are the same with the provisions of the Charter 4 of the 1979 constitution, a citizen cannot have recourse to it.

3. By virtue of Article 1 of the African Charter on Human and Peoples' Rights, the member states of the Organisation of African Unity, parties to the Charter, shall recognise the rights, duties and freedoms enshrined in the Charter and shall undertake to adopt legislative or other measures to give effect thereto.

4. By virtue of Section 1 of the African Charter on Human Rights (Ratification and Enforcement) Act, Cap. 10 Laws of the Federation of Nigeria, 1990, the provisions or the

\footnotetext{
${ }^{44}$ Suit No M/462/93; Reported in Eze Onyekpere (ed). Manual on the Judicial Protection of Economic Social and Cultural Rights.

${ }_{45}$ Suit No. M/462/93: Reported in Eze Onyekpere (ed). Manual supra.

46 (1996) 9 NWLR (Pt 475) 710.
} 
African Charter on Human and Peoples Rights shall, subject to as hereinafter provided, have force of law in Nigeria and shall be given full recognition and effect and be applied by all authorities and persons exercising legislative, executive or judicial powers in Nigeria. Nigeria incorporated the Charter on Human and Peoples Rights to its statue books because it is a signatory to the convention; by signing same and incorporating it into law seeks to act in accord with the dictates of Section 12(1) of the 1979 Constitution.

On further appeal to the Supreme Court it was held amongst others as follows:

1. The African Charter, as far as Nigeria is concerned, is not purely a matter of public international law (or international customary law, per se) regulating the relationship between member states which are signatories to it, it is an understanding between some African States concerned to protect and improve the human rights and dignity of their citizens and other citizens within the territorial jurisdiction of their countries to the commitment of which that understanding has been translated into a legal obligation by adopting the Charter as a domestic law. ${ }^{47}$

2. The Charter gives to citizens of member states of the Organisation of African United rights and obligations, which rights and obligations contained in the Charter, are not new to Nigeria as most of these rights and obligations are already enshrined in our constitution. ${ }^{48}$

3. The individual rights contained in the articles of the African Charter on Human and People's Right are justiceable in Nigerian courts. Thus, the articles of the Charter show that individuals are assured rights which they can seek to protect from being violated and if violated to seek appropriate remedies; and it is in the national courts such protection and remedies can be sought and if the case is established, enforced. ${ }^{49}$

In Nigeria National Petroleum Corporation v. Chief Fawehinimi and others ${ }^{50}$, the Court of Appeal held that a party who claims that Article 3 of the African Charter on Human and Peoples Rights has been or is likely to be infringed in regard to him must show (i) that he belongs to that class within which there has been inequality of treatment; (ii) that there is a classification for the purpose of application of the particular law; (iii) that the classification is arbitrary or irrational or otherwise impermissible.

In the case of Mojekwu and others v. Ejikeme and others ${ }^{51}$, involving Nnewi and "oliekpe" customs, tobi, JCA, referred to his earlier decision in Augustine Mojekwu v. Caroline Mojekwu $u^{52}$ and said:

"But I can say that the Nnewi custom relied upon by the respondents, which permitted them to inherit the estate of Reuben merely because he had no male child surviving him, is repugnant to natural justice, equity and good conscience. And what is more, such a custom has clearly discriminated against Virginia, the daughter of Reuben and therefore is unconstitutional, in the light of the provisions of section 52 of the Constitution of the Federal Republic of Nigeria, 1999. Article 14 of the European Convention of Human Rights contains generally similar provision. Article 18(3) of the African Charter on Human and People's Right specifically provides for the elimination of discrimination against women, a provision which is consistent with the Convention on the Elimination of all forms of Discrimination against Women (CEDAW)".

The cases made reference to two international conventions: the European Convention on Human Rights; the African Charter on Human and Peoples' Right. There is need to

\footnotetext{
47 Ibid.

${ }^{48}$ Ibid, per Ogundare J.S.C.

49 Supra.

${ }^{50}$ C.A/E/7/99 delivery on 9 December, (1999); see Eze Onyekpere (ed.) Manual on Judicial Protection of Economic, Social and Cultural Rights, a publication of shelter rights initiative 2000, p. 142.

51 (1997) 7 NWLAR (pt. 512) 283.

52 (1990) 7 NWLR (pt.163) 489 at 507.
} 
mention that in the Nigerian case of Oshevire v. British Caledonian Airways Ltd. ${ }^{53}$, the Court of Appeal held that international agreement embodied in a convention or treaty is autonomous, as the parties contracting have submitted themselves to be bound by its provisions, which are therefore above domestic legislation. Thus, any domestic legislation in conflict with the convention is void. The court held that the Warsaw Convention, as amended by the Hague protocol, which was ratified by Nigeria, prevails over the rules of domestic law, when they are incompatible with the latter. It is clear from the above that not much has happened in Nigeria in respect of domestic application of Housing and other ESC rights by her national courts. There are two basic reasons. First, ESC rights are not provided for in chapter four of the constitution but are contained in chapter two which are not justiciable. Secondly, litigants are not fully aware of their ESC rights, - particularly in the context of international conventions like the African Charter on Human and Peoples' Right and this calls for proper education. The point is considered that it will take some time before the public will fully enforce their ESC rights in the same way they enforce their chapter four rights in the constitution. The Nigeriia judiciary is hereby called upon to interpret chapter four rights, in a way that gives life to the provisions of chapter two on fundamental objections and directive principles of state policy.

For instance, in Tellis v. Bombay Municipal Corporation ${ }^{54}$ slum dwellers brought an action to prevent eviction from their shelter without provision for adequate alternative accommodation. They contended that their eviction would deprive them of their economic livelihood and hence their rights to life under article 21 of the Indian constitution, because their shelters were the only place where they could reside in close proximity to their employment. The Indian Supreme Court agreed and stated thus:

"The sweep of the right to life conferred by article 12 is wide and far reaching. It does not mean merely that life cannot be extinguished... and, for example, by imposition and execution of the death sentence, except in accordance with a procedure established by law. All equally important facet to that life is the right to livelihood, because no person can live without the means of living, that is, the means of livelihood... Deprive a person of his right to livelihood and you shall have deprived him of his life".

Thought this may appear ambitious on the face of it in this country, yet case law from other jurisdictions confirms the possibility of such application. ${ }^{55}$

\section{Conclusions}

In this paper, I argue a case for a right to housing as a fundamental human right. My analysis was confined to the effect of the use of regulatory schemes as a source of protection and, particularly, I am concerned with a consideration of examples of these schemes viz: the Rent Control and Recovery of Residential Premises laws and the Land Use Act. It is observed that the intrusion of regulatory schemes offer less elaborate protection for the right to housing than the citizens themselves getting directly involved from the level of human rights adjudication. It is also observed that the right to adequate housing is a right of every citizen of Nigeria to live somewhere in security, peace, liberty and dignity. In this regard, the role of the government may not translate directly into building houses for every needy member of the society; rather, it extends to providing the enabling socio-economic and political climate necessary for the fulfilment of this right through legislation, and readiness of the state to ratify and comply with the provisions of international human rights instruments on the right to housing. It follows, therefore, that the challenges of the issue of adequate housing require commitment and changes in behavioural approach to the distribution of national resources in favour of the under-privileged in the society.

\footnotetext{
${ }^{53}$ (1990) 7 NWLR (pt. 163) 507.

54 (1986)( AIR (SP. Ct) 180.

55 See Bromor v. Ekiyor (1985) HCNLR 987 at 989. See also Manual on Housing Rights. Supra at p. 28.
} 